\title{
HYDROBIOLOGICAL STUDIES ON IBIEKUMA RIVER AT EKPOMA, SOUTHERN NIGERIA, AFTER IMPOUNDMENT: THE FAUNAL CHARACTERISTICS
}

\author{
Clement Aghatise Edokpayi* and Ekikhalo Catherine Osimen** \\ *Department of Zoology, Marine Biology and Fisheries, \\ University of Lagos, Akoka, Lagos, Nigeria. \\ **Ambrose Alli University \\ P.M.B. 14, Ekpoma, Edo State, Nigeria.
}

\begin{abstract}
A study of a $3 \mathrm{Km}$ stretch of a perennial rainforest stream in southern Nigeria describes the macrobenthic faunal characteristics of pools (dam site stations) and runs. A total of 84 invertebrate taxa made up of 2,535 individuals were recorded. The overall faunal abundance was not significantly different at the study stretch. The abundance of the major taxonomic groups was however significantly different $(P<0.05)$ at the study stations. Hemiptera and Diptera were the most abundant invertebrate groups recorded. The high number of benthic invertebrates observed is a reflection of the physical and chemical stability of the study stream.
\end{abstract}

Keywords: Rainforest stream; Macrobenthic fauna; Nigeria; Impoundment

\section{INTRODUCTION}

This paper is the second of two papers on the postimpoundment hydrobiological studies of a perennial rainforest stream in southern Nigeria. This first paper (in press) deals with the fluctuations in the physical and chemical characteristics of the stream after the dam construction. Pre-impoundment ecological investigations on the stream are available (Idamughe, 1987; Okenyi, 1991; Edokpayi and Gbugbemi, 1998). The present paper presents the results of a study conducted to evaluate the macrobenthic faunal characteristics of the Ibiekuma stream after impoundment

\section{STUDY AREA}

The Ibiekuma stream is a perennial First Order rainforest stream in Ekpoma, southern Nigeria (Lat. $6^{\circ} 00 \notin \mathrm{N}, 6^{\circ} 06 \notin$ $\mathrm{S}$; Long. $\left.6^{\circ} 00 \notin \mathrm{E}, 6^{\circ} 05 \notin \mathrm{W}\right)$. The stream takes its source within the Ambrose Alli University permanent site (Fig. 1) and joins other rivers one of which empties into the Atlantic Ocean (Udo, 1970; Aiboni, 1988).

The study area is characterized by flat land surface, easily worked sandy loam soils. Geologically, the area is composed of the basement complex of the Precambrian era. The Ibiekuma stream overlies detritus of Bendel Ameki Shales and sandstones with a unique toposequence (Aiboni, 1988). The University impounded the stream in 1993, with assistance from the EEC primarily to supply water to the University community and its environs.
Farming is the major human activity in the study area. The main crops cultivated are cassava, yam, rice and corn.

For this survey, three stations within $3 \mathrm{Km}$ stretch of the stream were recognized (Fig. 1). All the samples were collected from the bank-root biotope. Station 1 is about $700 \mathrm{~m}$ upstream of the Gravity dam with no visible unidirectional flow. The depth at this site is about $0.45 \mathrm{~m}$ with an average width of $3 \mathrm{~m}$. It is shaded with fringing vegetation of mainly shrubs like Sagitaria sagittifolia and Phonix palm. The substratum is mainly coarse sand and granite mixed with clay and large quantities of allochthonous matter, mainly logs and leaves of reparian vegetation. Human activity at this site is limited to occasional fishing and idol worshipping.

The upstream face of the dam with a depth of $1.5 \mathrm{~m}$ and width of $10.2 \mathrm{~m}$ locate station 2 . This station is unshaded with visible unidirectional flow. Bankroot vegetation was mainly grass such as Andropogon techtorum, Digitaria sp., Penisetum sp., and Talinum triangulare. The substratum is coarse sand and granite. Human activities include bathing and washing of implements by rubber tapers. 
Hydrobiological Studies on Ibiekuma River at Ekpoma, Southern Nigeria, after Impoundment: The Faunal Characteristics

Figure 1 (a) Hep of Nigoria ahowing the pouttion of Edo Bteto,

(b) Edo Stete shovide the position of Ekpone; and

(c) Bkpome thoving the locetion of the study stations.

(A)

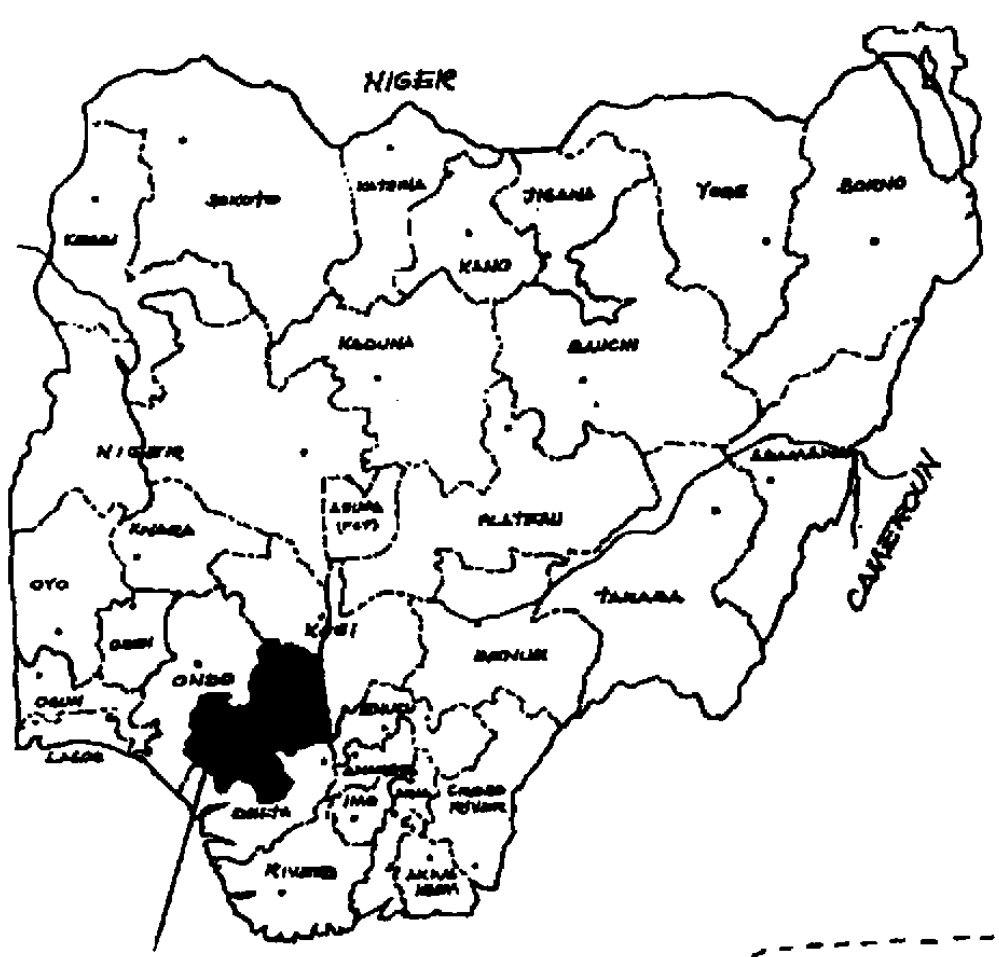

Edo State
(B)

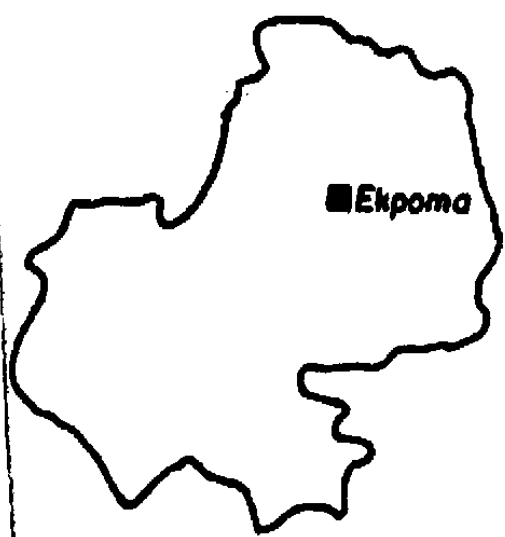

(C)
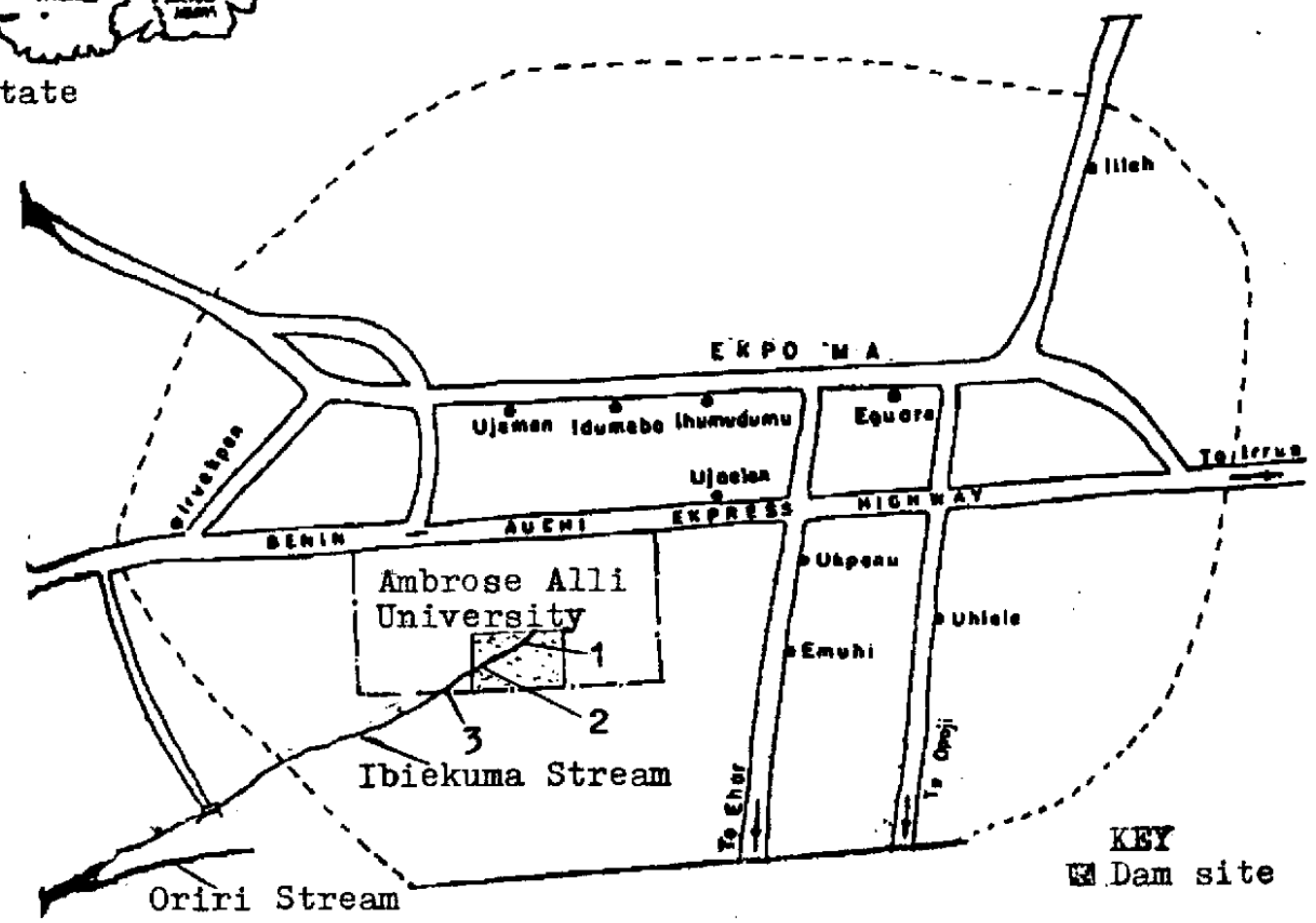
Station 3 is located about $2.3 \mathrm{~km}$ downstream of station 2 . The stream channel at this site is narrow of about $0,36 \mathrm{~m}$ deep and $1.0 \mathrm{~m}$ wide. It is shaded with trees (Alstonia boonei, Nauclea diderrchi, Havea braziliensis and Eleasis guinensis) and shrubs (Dryopteris sp., Sagittaria sagittifolia, Smilax krussiana and Phoenix palm). The stream is fast flowing at this station. The substratum is sand mixed with decaying leaves and fallen logs. A summary of the physical and chemical conditions of the study stations is presented in table 1 .

Table1 The composition, distribution and abundance of macrobenthic invertebrates in Ibiekuma stream; February to August, 1995; Numbers indicate abundance; - indicates absence.

\begin{tabular}{|c|c|c|c|c|c|c|c|c|}
\hline & \multicolumn{2}{|c|}{ STATION 1} & \multicolumn{2}{|c|}{ STATION 2} & \multicolumn{2}{|c|}{ STATION 3} & \multicolumn{2}{|c|}{ OVERALL } \\
\hline & $\begin{array}{l}\text { No. of } \\
\text { Taxa }\end{array}$ & $\begin{array}{l}\text { No. of } \\
\text { individuals }\end{array}$ & $\begin{array}{l}\text { No. of } \\
\text { Taxa }\end{array}$ & $\begin{array}{l}\text { No. of } \\
\text { individuals }\end{array}$ & $\begin{array}{l}\text { No. of } \\
\text { Taxa }\end{array}$ & $\begin{array}{l}\text { No. of } \\
\text { individuals }\end{array}$ & $\begin{array}{l}\text { No. of } \\
\text { Taxa }\end{array}$ & $\begin{array}{l}\text { No. of } \\
\text { individuals }\end{array}$ \\
\hline \multicolumn{9}{|l|}{ ANNELIDA } \\
\hline Naididae & 3 & 7 & 3 & 5 & 3 & 4 & 9 & 16 \\
\hline Tubificidae & - & - & 1 & 2 & - & - & 1 & 2 \\
\hline \multicolumn{9}{|l|}{ INSECTA } \\
\hline \multicolumn{9}{|l|}{ COLEOPTERA } \\
\hline Hydrophilidae & 1 & 2 & - & - & 1 & 1 & 2 & 3 \\
\hline Dytiscidae & 2 & 4 & - & - & 1 & 1 & 3 & 5 \\
\hline Hydrinidae & 1 & 2 & - & - & - & - & 1 & 2 \\
\hline Helodidae & 1 & 1 & - & - & - & - & 1 & 1 \\
\hline \multicolumn{9}{|l|}{ Elmidae } \\
\hline a. Family type A & 1 & 1 & - & - & - & - & 1 & 1 \\
\hline b. Family type B & - & - & - & - & 1 & 1 & 1 & 1 \\
\hline Halipidae & 1 & 1 & - & - & - & - & 1 & 1 \\
\hline \multicolumn{9}{|c|}{ UNIDENTIFIED FAMILY } \\
\hline a. Family type A & 1 & 2 & 1 & 2 & - & - & 2 & 4 \\
\hline b. Family type B & 1 & 1 & - & - & - & - & 1 & 1 \\
\hline \multicolumn{9}{|l|}{ COLLEMBOLA } \\
\hline Isotomidae & 1 & 6 & - & - & 1 & 4 & 2 & 10 \\
\hline \multicolumn{9}{|c|}{ EPHEMEROPTERA } \\
\hline Baetidae & 1 & 191 & 1 & 116 & 1 & 27 & 3 & 334 \\
\hline Ephemeridae & 1 & 1 & - & - & 1 & 2 & 2 & 3 \\
\hline Siphlonuridae & 1 & 1 & 1 & 1 & 1 & 1 & 3 & 3 \\
\hline \multicolumn{9}{|l|}{ HEMIPTERA } \\
\hline Nepidae & 2 & 3 & 2 & 2 & 1 & 1 & 5 & 6 \\
\hline Pleidae & 1 & 1 & 1 & 1 & - & - & 2 & 2 \\
\hline Coroxidae & 1 & 777 & 1 & 134 & 1 & 78 & 3 & 989 \\
\hline Naucoridae & 1 & 3 & 1 & 4 & - & - & 2 & 7 \\
\hline Mesoveliidae & 1 & 1 & - & - & - & - & 1 & 2 \\
\hline Notonectidae & 1 & 2 & - & - & - & - & 1 & 2 \\
\hline Gerridae & 1 & 1 & - & - & - & - & 1 & 1 \\
\hline a. Family type A & 1 & 1 & 1 & 2 & - & - & 2 & 3 \\
\hline b. Family type B & 1 & 2 & - & - & - & - & 1 & 2 \\
\hline \multicolumn{9}{|l|}{ ODONATA } \\
\hline Aeschnidae & 1 & 1 & - & - & - & - & 1 & 1 \\
\hline Petaluridae & 1 & 1 & 1 & 2 & - & - & 2 & 3 \\
\hline Libellulidae & 3 & 9 & 5 & 9 & - & - & 8 & 18 \\
\hline
\end{tabular}


Hydrobiological Studies on Ibiekuma River at Ekpoma, Southern Nigeria, after Impoundment: The Faunal Characteristics

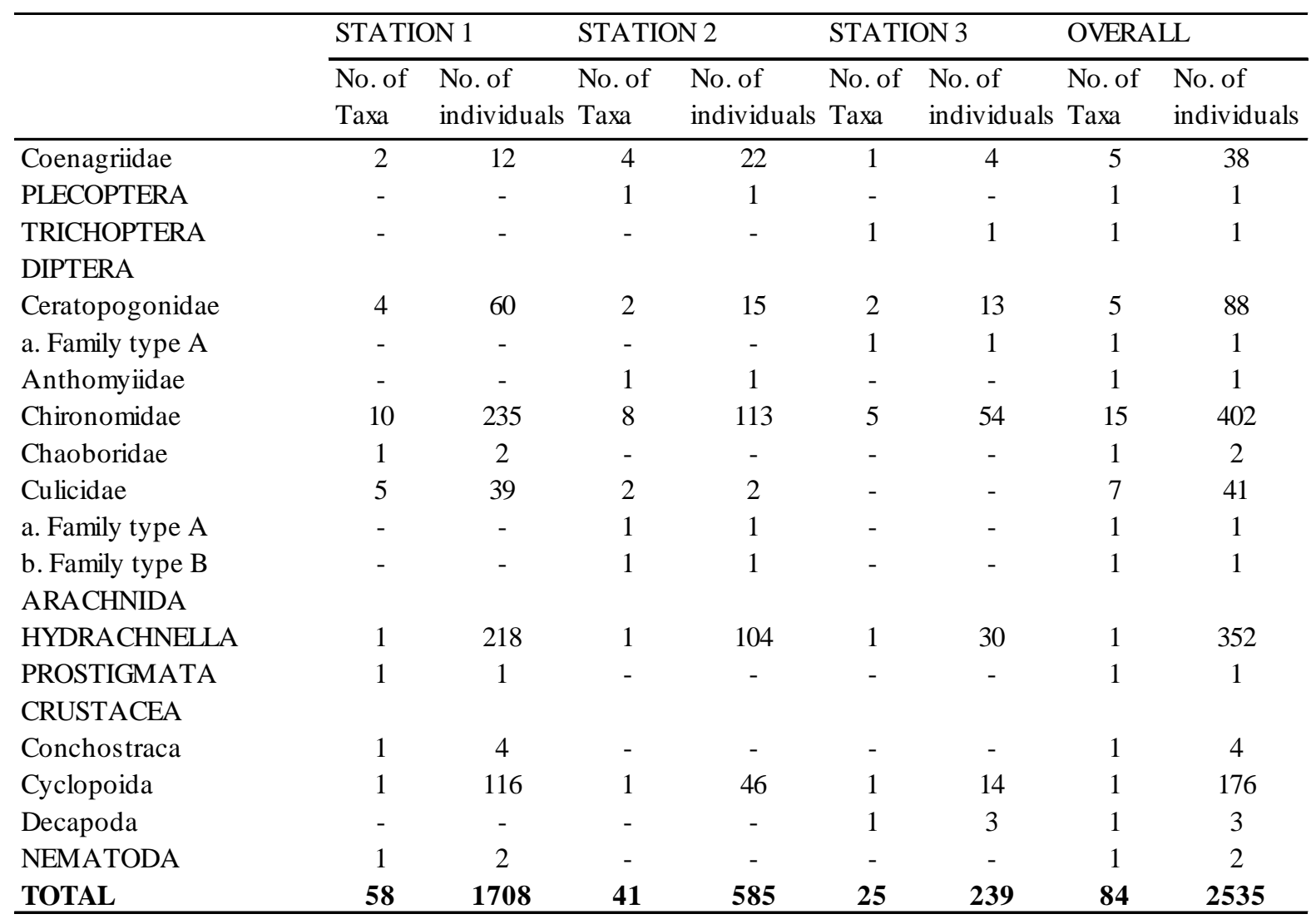

\section{METHODS}

The macrobenthic sampling program covered a period of seven months from February to August 1995. Fortnightly samples were taken between $0800 \mathrm{~h}$ and $1200 \mathrm{~h}$ on each sampling day. Samples were collected using the kick sampling technique (Hynes, 1970) and analyzed using standard procedures (Lenat et al., 1981; Victor and Ogbeibu, 1985; Ogbeibu and Egborge, 1995). All benthic samples were fixed in the field using small quantities of $40 \%$ formalin. Further analyses carried out in the laboratory include sieving (mesh size $1.4 \mathrm{~mm}-250 \mathrm{~mm}$ ) and isolation of fractions were examined under suitable magnifications (7 $-40 \mathrm{X})$. The benthic fauna was sorted and preserved either in $10 \%$ formalin or $70 \%$ methanol. The macrobenthic invertebrates were identified using manuals listed in Ogbeibu and Egborge (1995).

All statistical procedures, were appropriate, were adopted from Zar (1984). SPSS 6.5 window application and Excel were used for the calculations and to plot the graph respectively.

\section{RESULTS}

Eighty-nine invertebrate taxa (2,535 individuals) were collected in the stream during the entire study period. Table 2 lists the higher taxonomic categories of invertebrates, the number of taxa recognized within each category, their distribution and abundance at the three study stations. The overall abundance of fauna was highest at station 1 (1708) and lowest at station III (239) (Fig. 2). Wide fluctuations in the abundance of major taxonomic groups were observed among the study stations (Fig. 3). Aquatic insects where more abundant representing over $86 \%$ and $78 \%$ respectively of the overall taxa and individuals recorded (Fig. 4). The dominant insect taxa were the ubiquitous Corixa sp. (Hemiptera: Corixidae); Chironomus sp., Chryptochironomus sp., Polypedolum sp. and Tanytasus sp. (Diptera: Chironomidae); Baetis sp. 
Table 2. Summary of the physical and chemical conditions at the Ibiekuma River study stations; Mean ( \pm S.E.) values (except that of $\mathrm{pH}$ ) are given (minimum and maximum are in parenthesis), February to August 1995 .

\begin{tabular}{|c|c|c|c|}
\hline PARAMETERS & STATION I & STATION 2 & STATION 3 \\
\hline \multirow{2}{*}{ Air Temperature $\left({ }^{\circ} \mathrm{C}\right)$} & $31.0 \pm 0.67$ & $30.8 \pm 0.69$ & $30.5 \pm 0.72$ \\
\hline & $(27.0-36.0)$ & $(27-36)$ & $(27-36)$ \\
\hline \multirow{2}{*}{ Water Temperature $\left({ }^{\circ} \mathrm{C}\right)$} & $28.71 \pm 0.35$ & $28.8 \pm 0.32$ & $28.5 \pm 0.37$ \\
\hline & $(26.0-31.0)$ & $(26-30)$ & $(26-30)$ \\
\hline \multirow[t]{2}{*}{ Water Level (m) } & $0.54 \pm 0.02$ & $1.54 \pm 0.01$ & $0.36 \pm 0.11$ \\
\hline & $(0.44-0.66)$ & $(1.50-1.59)$ & $(0.31-0.46)$ \\
\hline \multirow[t]{2}{*}{ Flow Velocity $(\mathrm{Cm} / \mathrm{Sec})$} & 0.00 & $0.059 \pm 0.008$ & $0.35 \pm 0.01$ \\
\hline & & $(0.023-0.091)$ & $(0.29-0.38)$ \\
\hline \multirow[t]{2}{*}{ Transparency (m) } & $0.51 \pm 0.01$ & $0.69 \pm 0.037$ & $0.36 \pm 0.01$ \\
\hline & $(0.42-0.62)$ & $(0.40-0.87)$ & $(0.31-0.45)$ \\
\hline \multirow[t]{2}{*}{ Total Suspended Solid (mg/L) } & $3406.78 \pm$ & $3954.07 \pm$ & $3431.29 \pm 542.25$ \\
\hline & $(1090-9910)$ & $(1110-8820)$ & $(1121-6970)$ \\
\hline \multirow[t]{2}{*}{ Conductivity $(\mu \mathrm{S} / \mathrm{Cm})$} & $40.03 \pm 13.76$ & $30.38 \pm 11.38$ & $27.49 \pm 8.39$ \\
\hline & $10.56-$ & $(10.11-$ & $(11.10-117.40)$ \\
\hline PH & $(4.60-6.40)$ & $(4.80-6.30)$ & $(4.50-5.70)$ \\
\hline \multirow[t]{2}{*}{ Total Alkalinity $\left(\mathrm{mgCaCO}_{3} / \mathrm{L}\right)$} & $5.90 \pm 0.56$ & $5.36 \pm 0.69$ & $6.43 \pm 0.77$ \\
\hline & $(2.50-10.00)$ & $(0.00-10.00)$ & $(2.50-10.00)$ \\
\hline \multirow[t]{2}{*}{ Dissolved Oxygen (mg/L) } & $8.81 \pm 0.48$ & $9.28 \pm 0.49$ & $10.83 \pm 0.53$ \\
\hline & $(6.80-13.00)$ & $(7.40-12.30)$ & $(8.80-15.30)$ \\
\hline \multirow{2}{*}{$\begin{array}{l}\text { Biochemical Oxygen Demand } \\
\text { (mg/L) }\end{array}$} & $2.00 \pm 0.12$ & $1.71 \pm 0.21$ & $1.75 \pm 0.39$ \\
\hline & $(0.80-2.6)$ & $(1.00-3.20)$ & $(0.80-2.40)$ \\
\hline \multirow[t]{2}{*}{ Calcium (mgCaCO $\left.\mathrm{I}^{\mathbf{1}}\right)$} & $3.04 \pm 0.04$ & $2.11 \pm 0.48$ & $2.69 \pm 0.06$ \\
\hline & $(2.40-4.01)$ & $(1.50-3.21)$ & $(1.60-4.01)$ \\
\hline \multirow[t]{2}{*}{$\mathrm{NO}_{3}-\mathrm{N}\left(\mathrm{mgl}^{-1}\right)$} & $0.94 \pm 0.059$ & $0.9 \pm 0.32$ & $0.9 \pm 0.02$ \\
\hline & $(0.19-3.56)$ & $(0.25-2.06)$ & $(0.63-1.28)$ \\
\hline \multirow[t]{2}{*}{$\mathrm{PO}_{3}-\mathrm{P}\left(\mathrm{mgl}^{\mathbf{l}}\right)$} & $1.99 \pm 0.029$ & $1.83 \pm 0.03$ & $1.9 \pm 0.13$ \\
\hline & $(1.07-2.31)$ & $(1.49-2.31)$ & $(0.83-2.23)$ \\
\hline
\end{tabular}

(Ephemeroptera: Baetidae) and the Arachnida which accounted for about $14 \%$ of the overall abundance were dominated by Arranurus sp. and Hydrophantes sp. (Hyrachnella) (Table 2, Fig. 4). Nematodes and crustaceans were poorly represented at the study stretch, while molluscs were not recorded throughout. In general, there was no statistical difference $\left(\mathrm{F}_{0.05,111}=2.317\right)$ in the overall abundance and distribution of the benthic invertebrate at the study sites.

\section{DISCUSSION}

The total number of invertebrate taxa (84) recorded in this stream is relatively high when compared to other temperate (Tsui and McCart, 1981; Lenat et al., 1981), arid (Victor and Al-Mahrouqi, 1996) and some topical (Victor and Ogbeibu, 1985; Ogbeibu and Egborge, 1995; Oribhabor, 1995; Umeozor, 1995) streams. Pre-impoundment studies on this stream also recorded lower invertebrate taxa (Okenyi, 1991, Edokpayi, et al., unpublished data). Diversity tends to be 
Hydrobiological Studies on Ibiekuma River at Ekpoma, Southern Nigeria, after Impoundment: The Faunal Characteristics

Fig. 2. The overal percentage abundance in the number of taxa and individuals at the study stations

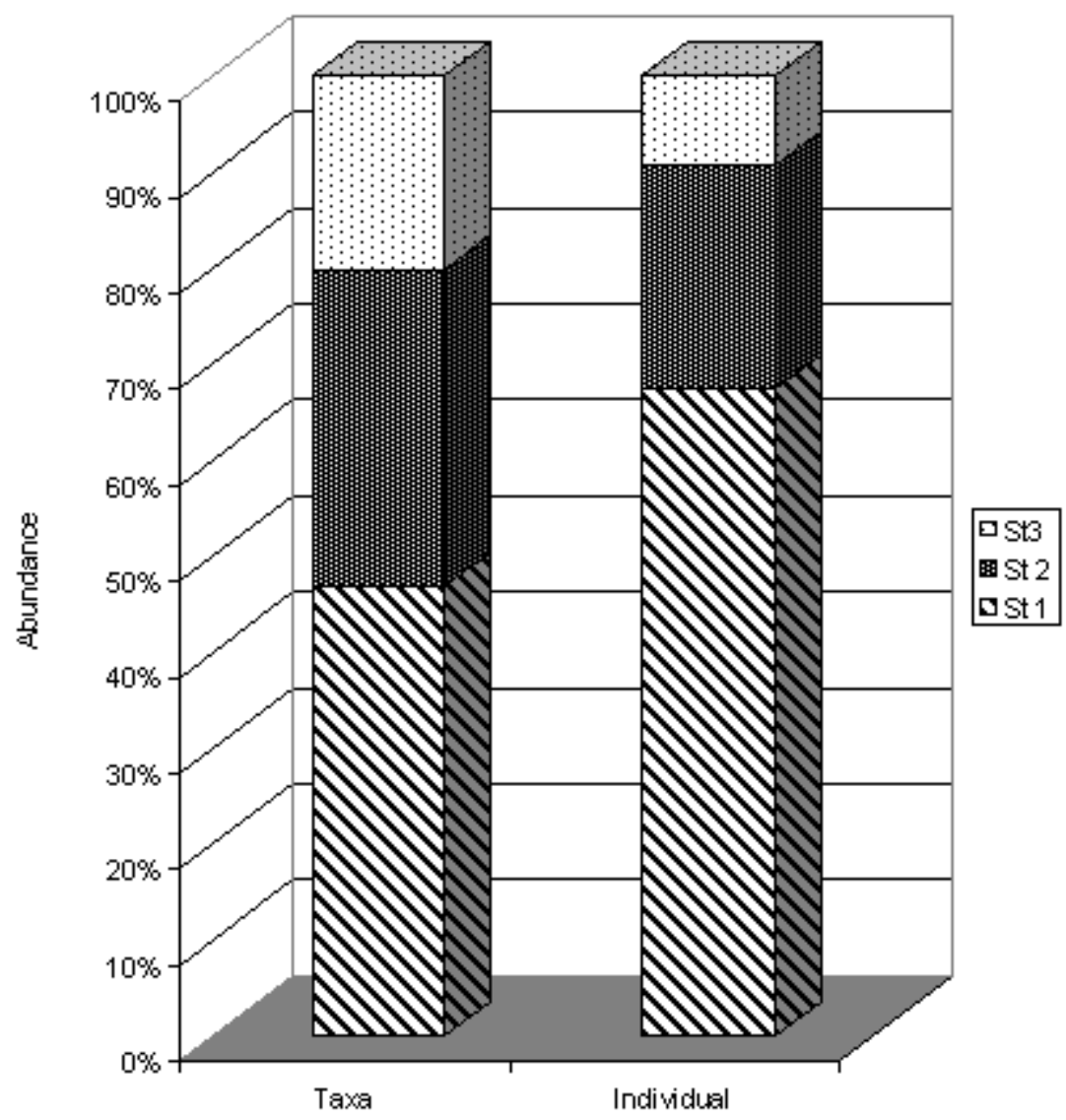


Fig. 3. The relative percertage abundanoe in the number of taxa and individuas of the major taxonomic groups at the study stream

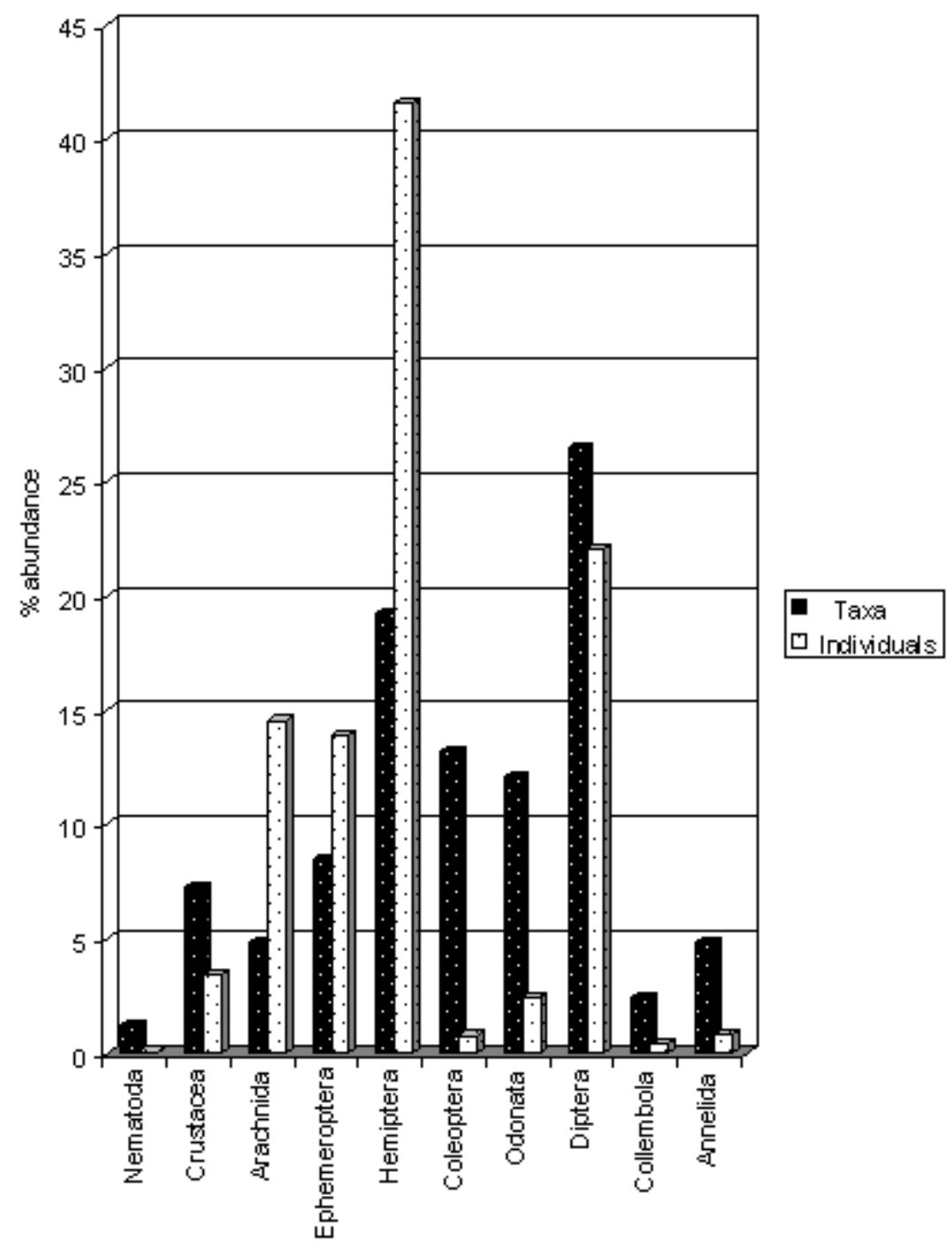




\section{Hydrobiological Studies on Ibiekuma River at Ekpoma, Southern Nigeria, after Impoundment:}

The Faunal Characteristics

Fig. 4. Fluduations in the peroentage abundance in the number of taxa and individuals of the major taxonomic groups at the study stations

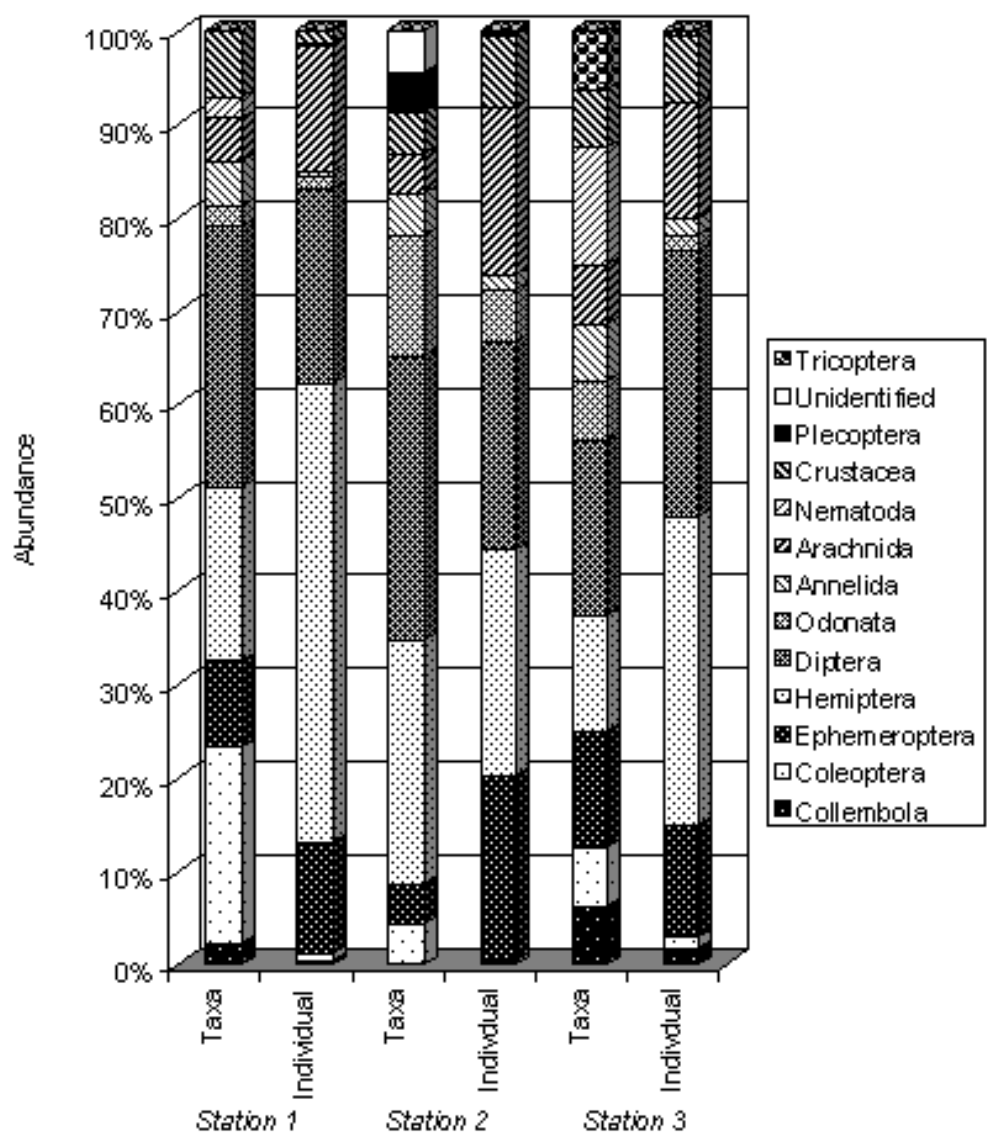

low in physically controlled systems (Odum, 1971). The high number of benthic invertebrates recorded here is a reflection of the stability of the physical and chemical characteristics of the study stream.

Insects were the most dominant group of invertebrate recorded in this study. Corixidae (Hemiptera) was responsible for this high abundance. Corixides have been reported to contribute greatly to the abundance of invertebrate in most water bodies (Pennark, 1953), except those low in dissolved oxygen (Ogbeibu, 1987, Oribhabor, 1995). The dissolved oxygen content of the surface waters at the study sites were high (Table 2) and similar to those reported for most tropical waters of unpolluted rivers (Ogbeibu and Victor, 1995). This high oxygen concentration may have influenced the dominance of hemiptera at the study stretch. The occurrence of Beatidae and Chronomidae in high abundance in this study is not unusual as this group of invertebrates have been reported to be common and major components of tropical streams (Victor and Ogbeibu, 1985; Victor and Matthew 1989; Ogbeibu and Victor, 1989; Victor and Al-Mahrouqi, 1996). The taxonomy and ecology of aquatic arachnids is poorly understood in Nigeria (Egborge, 1993). Hydrachnella (Arachnida) are usually abundant among aquatic weeds and plant debris (Cook, 1966). The increase in water level due to impoundment may have resulted in increase in shoreline and subsequent flooding of riparian vegetation. This could have encouraged the increase in abundance of hydrachnella observed in this study.

The occurrence of crustaceans was low, while mollusks 
were not observed at the study stretch. Sedimentation due to impoundment (Baxter and Glaude, 1980), low pH and calcium content (Table 1) of the study stream may have contributed to the paucity of crustaceans and mollusk (Laurie, 1987).

\section{REFERENCES}

Aiboni, V. (1988). Soils of a toposequence in Ekpoma, Bendel State. Paper presented at the $16^{\text {th }}$ Annual Conference of Soil Science Society of Nigeria, Minna.

Baxter, R.M. \& Glaude, P. (1980). Environmental effects of dams and impoundments in Canada: Experiences and Prospects. Can. Bull. Cook, D.R. (1966). The water mites of Liberia. Memoirs Amer. Entomol. Inst. No. 6. Ann. Arbor.

Edokpayi, C.A. and Gbugbemi, O. (1998) A preliminary survey of the fish species composition in the Ibiekuma River headwaters before the dam construction. Nigerian Annals of Natural Sciences, Vol. 4: $10-15$.

Egborge, A.B.M. (1993). Biodiversity of Aquatic Fauna in Nigeria. Natural Resources Conservation Council, Abuja. 173p.

Hynes, H.B.N. (1970). The Ecology of Running Waters. University of Toronto Press, Toronto. 555p.

Idamughe, A. (1987). The hydrology and macrobenthic invertebrates of Ibiekuma Stream, a tributary of river Orhionmwon, Bendel State. B.Sc. Thesis, Bendel State University, Ekpoma, Nigeria.

Laurie, E.F. (1987). The diversity of macroinvertebrate and macrophyte communities in ponds. Freshwater Biol. 18: $87-104$.

Lenat, D.R., Penrose, D.L. and Eagleson, K.W. (1981). Variable effects of sediment addition on stream benthos. Hydrobiologia. 79: 187 - 194.

Odum, E.P. (1971). Fundamentals of Ecology. $3^{\text {rd }} \mathrm{ed}$. London, W.B. Sanders. 546p.

Ogbeibu, A.E. (1987). The effect of road and bridge construction on the macrobenthic invertebrates of the Ikpoba River, Benin City. M.Sc. Thesis, University of Benin, Benin City, Nigeria.
Ogbeibu, A.E. and Victor, R. (1989). The effect of road and bridge construction onbankroot macrobenthic invertebrates. Environ. Pollut. 56: 58 - 100.

Ogbeibu, A.E. and Egborge, A.B.M. (1995). Hydrobiological studies of water bodies in the Okomu Forest Reserve (Sanctuary) in Southern Nigeria. 1. Distribution and Diversity of the invertebrate fauna. Tropical Freshwater Biology 4: 1-27.

Ogbeibu, A.E. \& R. Victor (1995). Hydrobiological studies of water bodies in the Okomu Forest Reserve (Sanctuary) in Southern Nigeria. 2: Physical a $\mathrm{n} \mathrm{d}$ Chemical hydrology. Tropical Freshwat. Biol., 4, 83 -100 .

Okenyi, C.J. (1991). Effect of human activities on macrobenthic invertebrates of Ibiekuma River in Ekpoma, Bendel State. B.Sc. Thesis, Bendel State University, Ekpoma, Nigeria.

Oribhabor, B. (1995). Effect of impoundment on the macrobenthic invertebrates of Ikpoba River, Benin City. B.Sc. Thesis, University of Benin, Benin City, Nigeria.

Osoata, A. O. (1994). Physico - chemical conditions of Ibiekuma River dam at Ekpoma, Edo State. B.Sc. Thesis, Edo State University, Ekpoma, Nigeria.

Pennak, R.W. (1953). Freshwater Invertebrates of the United States. The Ronald Press Company, New York. $761 \mathrm{p}$.

Tsui, P.T. and McCart, P.J. (1981). Effect of stream-crossing by a pipeline on the benthic macroinvertebrate communities of a small mountain stream. Hydrobiologia 19: 271 - 276.

Udo, R.K. (1970). Geographical Regions of Nigeria. p38. Heinemann Education Books Ltd. (Publishers) London.

Umeozor, O.C. (1995). Benthic fauna of New Calabar River, Nigeria. Tropical Freshwater Biology, 4: 41 - 51.

Victor, R. and Ogbeibu, A.E. (1985). Macrobenthic invertebrates of a Nigerian stream flowing through farmland in Southern Nigeria. Environ. Pollut. Ser. 39: $337-349$.

Victor, R. and Mathew, A.S. (1989). Ecology of cyclopoid copepods (Copepoda: Crustacea) in a tropical backwater pond. Trop. Freswat. Biol., 2(1), 130-140. 
Hydrobiological Studies on Ibiekuma River at Ekpoma, Southern Nigeria, after Impoundment: The Faunal Characteristics

Victor, R. and Al-Mahrouqi, A.I.S. (1996). Physical, Chemical and faunal characteristics of a perennial stream in arid northern Oman. Journal of Arid Environments, $465-476$.

Zar, J.H. (1974). Biostatistical Analysis Prentice - Italy, Inc., New Jersey. 